\title{
Pulp Horn
}

National Cancer Institute

\section{Source}

National Cancer Institute. Pulp Horn. NCI Thesaurus. Code C52670.

The portion of the pulp chamber that extends towards a cusp. 